\title{
Transurethral Prostatic Resection
}

National Cancer Institute

\section{Source}

National Cancer Institute. Transurethral Prostatic Resection. NCI Thesaurus. Code C15343.

Prostate tissue removal via a cystoscope. 